\title{
Governing through Normality: Law and the Force of Sameness
}

\begin{abstract}
This article claims that the existence of social groups hinges on the production of sameness, which allows distinguishing members from non-members. Sameness is described as a shared set of standards whereby social subjects can provide mutually understandable accounts of themselves, their practical activities, and their environment. The author argues that sameness is not an intrinsic property of groups, but is produced within the very practices that it is meant to support. By building on a Wittgensteinian interpretation of meanings and rules, he illustrates how sameness is an intrinsic feature of the process through which the members of a practice construct the latter by establishing its rules. At the same time, the article draws on Carl Schmitt's institutional thinking, elaborated in the 1930s, and particularly his analysis of the relevance of normality to the existence of law. In doing so, the author claims that sameness and normality are key, co-original aspects of there being an effective legal order. Against this analytical background, the article goes on to claim that the legal orders typical of liberal regimes hold sway on social practices through the protection of normality and the revision of its boundaries as new challenges arise. As a case in point, the author examines the hypothesis that today's push for legal recognition of same-sex marriage could be interpreted as an immunity response of liberal regimes to homosexual sexualities' former critique of traditional models of kinship.
\end{abstract}

Constructing sameness is an essential intellectual activity that goes unobserved (Douglas 1987, p. 60)

What is it that produces sameness? This is one of the most troubling questions for those who endeavour to understand how social order comes about and works. With no shred of doubt, this question has haunted the works of two major figures of the $20^{\text {th }}$ century, Carl Schmitt and Ludwig Wittgenstein, who have explored both the semantic implications of sameness and its pragmatic effects on the regulation of social interaction. Some scholars have drawn on Schmitt's and Wittgenstein's critical reflections to highlight the limits of liberalism (e.g. Mouffe 2000). Others have examined some of the connections among their theoretical concerns (e.g. Sluga 2011). Seldom, however, do interpreters pay due heed to Schmitt's and Wittgenstein's shared interest in the role of sameness and the way in which it helps produce conditions of normality. In the view of both, sameness and normality constitute the binary that enables social groups to exist qua groups, that is, to share standards of conducts and criteria of correctness. On this account, sameness can be conceptualised as the common reference to a set of criteria that confer social intelligibility and political speakability on social subjects. Put otherwise, sameness should not be regarded as a set of substantial properties that determine the homogeneity or the identity of social entities. It is rather a conceptual, cognitive devices that denotes, and draws the boundaries of, the "socially legible", in that it offers the standards whereby social subjects provide mutually understandable accounts of themselves, their practical activities, and their environment.

In the first three sections, I will mainly look at Wittgenstein's and Schmitt's insights into how sameness emerges and why it turns out to be so crucial to social order. On the one hand, Wittgenstein lays the theoretical foundation for the analysis of sameness, as he explains that the latter stems from, and depends on, a threefold relation among the creation of meanings, the observance of rules, and the development of practices. On the other hand, Schmitt's significant revision of the role of exception 
and his introduction of an institutionalist point of view emphasise the importance of the government of sameness for the stability and vigour of a political community.

Despite Wittgenstein's and Schmitt's relevance to my argument, however, the main purpose of this article is not to identify similarities and convergences between such notable and (for different reasons) controversial theorists. I will discuss them insofar as their analysis revolves around normality, an element of social life that other prominent authors, such as Pierre Bourdieu and Mary Douglas, consider to be key to understanding social order. Accordingly, in the other sections I will move on to the main concern of this article. I will use the analytical framework developed in the first three sections to understand how the liberal law ${ }^{1}$ governs normality, creates sameness, and responds to problematic situations in which sameness appears to be in jeopardy. The hypothesis I will advance is that governing society entails regulating social practices by protecting the type of sameness produced within them.

To substantiate my claim I will explore the current debate on the normalisation of lesbian and gay sexualities. In the last decades, a good deal of authors have drawn attention to the changing face of homosexuals' social struggles: if in the past the general discourse about homosexual sexualities was the vehicle for a broader critique of hegemonic conceptions of sex, love, family, and kinship, today's campaigns for homosexual rights are chiefly characterised by the pursuit of legal recognition and social acceptance under the aegis of the principle of equality. Studies on this transition are abundant and well documented. ${ }^{2}$ Nevertheless, my primary intent will be to focus on this issue so as to understand whether it can be read as the response of liberal regimes to a challenge that brings into question a model - the nuclear family based on coupledom - which is claimed to be both a natural unit and the cornerstone of society.

\section{Meanings as a principle of vision and division}

Wittgenstein's $(2009, \S 225)$ famous contention that " $[\mathrm{t}]$ he use of the word 'rule' and the use of the word 'same' are interwoven" aims to convey the idea that the first instantiation of a conduct by an agent and its reiteration on the part of other agents is key to the genesis of a rule. On this account, rule is synonymous with standard, while the latter is neither an abstract prescription nor the residue of a statistical recurrence. Something becomes a rule when it is adopted as a standard, that is, when it serves as something that allows performing a given action in the same way it was performed in a previous, paradigmatic instance. This first instance is paradigmatic because it determines the relevant conditions where the action has to be performed and offers a benchmark against which any further instance has to be assessed. Thus, the standard is an exemplar instance of a class to which it belongs, but for this very reason, it "steps out of its class in the very moment in which it exhibits and delimits it" (Agamben 1998, p. 22). In this regard, applying a word in the appropriate circumstances is the

\footnotetext{
${ }^{1}$ By "liberal law" or "the law of liberal regimes" I mean the legal systems of a range of political communities that share a specific cultural, historical, and socio-political tradition and are characterised by features such as constitutionalism and the rule of law. Despite significant differences in their actual legal and political mechanisms, these features are typical of both common law and civil law systems. Needless to say, differences among countries affect the way in which laws are produced and enforced or rights are established and recognized. And yet there are specific elements that pertain to the deep grammar of the national states emerged in Europe between the end of the confessional wars and the two world wars that, by and large, can be regarded as distinctive elements of liberal legal systems. For a broad (historical and conceptual) portrayal of how these systems have developed, as well as similarities and differences among them, see Costa and Zolo 2007.

${ }^{2}$ See e.g. Ammaturo 2014; Barker 2013; ANONYM.; Freeman 2002; Polikoff 2008.
} 
same as following a rule, to such an extent that grasping a meaning entails being involved in the practice whose borders are drawn by the paradigmatic instance.

This explains why Wittgenstein was so dissatisfied with the so-called picture theory of language (Hunnings 1988), which claims the meaning of a word to be the object that the word stands for. Such a view neglects the relevance of practices in the establishment of meanings. The first pages of Philosophical Investigations are entirely devoted to revealing the shortcomings of this conception of language. Wittgenstein excoriates the claim that what one needs to do in order to illustrate the meaning of a word is point to the object that the word aims to denote - like a teacher who wants to explain the meaning of a word to her pupil by ostention. Wittgenstein believes that what makes an act of ostention successfully illustrate the meaning of a word, and what allows a pupil to grasp the meaning of a word when the teacher points to the object to which the word refers, is the fact that the "normativity of the ostensive training of the novice is provided by society in the form of the teacher" (Williams 1999, p. 221). Ostention, as it were, forms part of a broader practice, whereby the teacher transfers to her pupil the skills for using the word in the appropriate circumstances.

In brief, acquiring a language and handling meanings amount to getting access to a practice and therefore to understanding what is appropriate in what circumstances. If this is true, then one's ability to assess the appropriateness of a circumstance eventuates in one's ability to determine when the situation is the same as the one in which she was explained how to use a given word. Speaking a language requires a practical skill in recognising sameness in different situations. This sameness, however, is not an inner property of the situation itself. As Mary Douglas (1987, p. 58) puts it, it would be "naïve to treat the quality of sameness, which characterizes members of a class, as if it were a quality inherent in things [...]. Comparison of cultures makes it clear that no superficial sameness of properties explains how items get assigned to classes". This is because sameness is the product of the practice itself, where a group of people stably associate the same words to the same objects in compliance with the paradigmatic instance. To put it otherwise, the meaning of a word and its implications come into light only within the relevant practice. In clarifying his methodological premises, David Schneider (1990, p. 4) insists on this point: "Simply knowing that a word can have many meanings, and simply knowing which are the many meanings a word can have, are not enough. What is necessary to know is which meanings apply when, and which of the many meanings does not apply or is not relevant under what circumstances".

This makes sense of Wittgenstein's $(2009, \S 199)$ conclusion that "[t]o follow a rule, to make a report, to give an order, to play a game of chess, are customs (usages, institutions)". This juncture recapitulates Wittgenstein's argument. If one follows a rule, then she is doing the same thing that she and others did in previous circumstances and that she and others will do again when appropriate circumstances arise (Baker and Hacker 2009, pp. 49-50). But Wittgenstein's insistence on rules being customs intends to remark that rules have no intellectual connection with the performance of an action in compliance with them (Taylor 1993). When agents guide their actions with reference to rules and explain what they do with reference to the rules that govern them, most of the times they perform a role, that is, they act as reporters, superiors, and chess players. Most of the times agents take on a role and abide by the rules that constitute such a role without any intellectual mediation between rules and their performance. Agents act as members of an institutional framework that bounds their practical knowledge and gets them to behave in accordance with the role they play in the here and the now.

Wittgenstein's lesson comes down to the conclusion that the bare connection between words and objects does not say anything substantial about the meaning of the former unless this connection 
is viewed through the lens of its first instantiation. Needless to say, in the flexible and dynamic scenario Wittgenstein has in mind, every application of a rule is placed in an intrinsic (and never mirroring) relationship to the paradigmatic instance. Sameness is not determined by comparison with a primeval instantiation, as every application of a rule renews and re-instantiates the latter. Moreover, the practice is always exposed to change as a new instance is taken as paradigmatic, in which case a new practice would be brought into life. However, within the actual practice the criteria to determine what is the same always depend on whether or not subsequent instantiations can be cognised and recognised (not so much intellectually as in the agents' actual conduct) in the light of a paradigmatic instance.

In other words, meanings always rest on a threefold relationship among words, objects, and the practice where the relevant connection between words and objects is established. Hence, acquiring meanings entails entering into an institutional framework and being trained to perform rules in accordance with the relevant circumstances demarcated by this framework. The very acquisition of meanings ipso facto instructs the members of an institutional framework on what to do in what circumstances and in compliance with the roles delineated therein. There is a coincidence between the cognitive side of the teaching-and-learning process and the pragmatic side of acquiring the skills that are indispensable in order for one to be part of a given institutional framework. This coincidence is superbly captured by Peter L. Berger and Thomas Luckmann (1966), as they shed light on the cognitive aspect of being involved in a practice and knowing what, within this practice, words stand for. In the picture they paint, there is a first-order objectivation of meanings, the process by which meanings are attached to things, and a second-order objectivation of meanings (which the authors call "legitimation"), whereby new meanings are produced that integrate the meanings already attached to things. The acquisition of the second type of meanings is key to the acquisition of the first, to such a degree that the latter cannot take place without the former. Berger and Luckmann write:

Legitimation "explains" the institutional order by ascribing cognitive validity to its objectivated meanings. [...] It is important to understand that legitimation has a cognitive as well as a normative element. [...] It always implies "knowledge" as well. For example, a kinship structure is not legitimated merely by the ethics of its particular incest taboos. There must first be "knowledge" of the roles that define both "right" and "wrong" actions within the structure. The individual, say, may not marry within his clan. But he must first "know" himself as a member of this clan. This "knowledge" comes to him through a tradition that "explains" what clans are in general and what his clan is in particular. [...] Legitimation not only tells the individual why he should perform one action and not another; it also tells him why things are what they are. In other words, "knowledge" precedes "values" in the legitimation of institutions (Berger and Luckmann 1966, p. 111).

Perhaps it should come as no surprise if Bourdieu mentions the same taboo when he introduces the parallel between categories and "accusations". In The Logic of Practice he explains how the categorisation of family structures are endowed with the symbolic power to constitute groups and to assign relative power to members. Yet, people have access to this structure by being instructed in the meanings of the words (say, sister) which constitute its framework and carry with themselves all the practical imperatives related to them. Accordingly, the ostensive teaching "this is your sister" is designed to instruct the brother on what he is supposed do to and not to do as a member of the kinship 
structure. Bourdieu continues by saying that, in the structuration of the social world, categories reveal their

etymological sense of collective, public imputations (kategoreisthai originally meant to accuse someone publicly), collectively approved and attested as self-evident and necessary. As such, they contain the magical power to institute frontiers and constitute groups, by performative declarations (one only has to think of all that is implied in a phrase like 'She's your sister,' the only practical statement of the incest taboo) that are invested with all the strength of the group that they help to make" (Bourdieu 1990, p. 170). ${ }^{3}$

In summary, not only do meanings circumscribe practices, define roles, and prescribe the conducts one has to perform when she takes on such and such a role. Meanings also incorporate and reflect power differentials that exist in the social world and make people learned about them.

To conclude, the light thrown thus far on the dialectic relationship between the cognitive and the pragmatic aspects of acquiring meanings tells us something important about the function of this process in the social realm. As rules give birth to institutional structures, ${ }^{4}$ they define relationships and hierarchies in the social space where practices take place. In this framework, meanings instruct people on what to do in given circumstances, what they are required to do when they take on a given role. Meanings, in this regard, operate as "cultural units", as they constitute "a set of rules which specify who should do what under what circumstances" (Schneider 1980, p. 5). In short, the organisation of the social realm as well as the constitution of groups within it rest on the production of meanings that allow members to take up a shared account of the institutional setting and, on the basis of it, to understand and follow the rules that are attached to their roles. This process, as I have argued above, is primarily carried out through the transmission and acquisition of the meanings that are constituted within the practice and, at the same time, constitute the practice. In this way, on the one hand, sameness is demarcated by the set of meanings that subjects come to possess and through which they come to adopt a "principle of vision and division" (Bourdieu 1998, p. 8). On the other hand, this very process makes subjects learned about the hierarchies and differentials of powers that meanings embody and confirm. This is evidence that the innocuous process of teaching and learning that Wittgenstein considers as key to humans establishing and following rules reveals itself as key also to the constitution of groups within society and the allocation of power among members.

\section{A Schmittian detour: from exception to normality}

One of the theoretical virtues of Schmitt's theory of law and politics is that it clearly brings to the surface the political nature of the process of signification in such a way that the intrinsic relationship between meanings and the institutional framework where they are produced is completely revealed. Meanings, he believes, mark out the territory of sameness by enabling people to determine what is the same as what. This is why political power has inevitably to do with meanings. And, eventually, what is Schmitt's sovereign if not a social semiologist? ${ }^{5}$ In effect, the decision of the Schmittian

\footnotetext{
${ }^{3}$ Bourdieu here is concerned with kinship categories and how they "institute a reality" (Bourdieu 1990, p. 172). However it is my claim that the process he describes extends to the general activity of producing categories and attaining distinction.

${ }^{4}$ I examine the process that leads loose and flexible sets of rules through institutionalisation in ANONYM.

${ }^{5}$ Famously, the opening lines of Schmitt's Political Theology conjure up the figure of the sovereign as the supreme decider on a state of exception, that is, a situation where no social and a fortiori legal order is in force: "Sovereign is he who decides on the state of exception" (Schmitt 2005, p. 5; translation slightly revised). As I will argue later on, the
} 
sovereign is intended to establish and stabilise a system of visible, perceptible, non-indifferent, socially pertinent differences - as Bourdieu (1998, p. 9) would have it - based on which people can recognise the enemy, or rather, the group or entity that is jeopardising the sameness of the political community. Schmitt's binary exception/decision aims to explain what permits a community to make the distinction, crucial to the community's own existence, between what is the same and what is different. In The Concept of the Political Schmitt exalts this understanding of politics when he avers that the foundational, existential conflict between friends and enemies is already-and-always contained in the semantic backdrop of the language of politics: "[A]ll political concepts, images, and terms have a polemical meaning. [They] are incomprehensible if one does not know exactly who is to be affected, combated, refuted, or negated" (Schmitt 1996, pp. 30-31).

These quotations, however, demonstrate that Schmitt in the 1920s still believes that sameness is conditional upon difference and distinction: first comes the exception, then comes normality. In that respect, Bourdieu and the Schmitt of the 1920s seem to concur, for both believe difference to be the existence condition for sameness. Something difficult to explain and capture, something magic and marvellous must be given which produces difference and enables the members of a given group or community to recognise each other: either the miraculous intervention of a god-like sovereign $\grave{a} l a$ $\mathrm{Schmitt}^{6}$, or the very mysterious act by which the state categorises reality and allocates stocks of power à la Bourdieu ${ }^{7}$.

Nevertheless, Schmitt himself came to realise how faulty this assumption is. Let me trace the path that led him to reject the idea that sameness is created by a sovereign. This will be key to understanding Schmitt's salient contribution to the conceptualisation of sameness.

Schmitt is well known for his contention that norms, in exceptional times, are inert and useless. His tirade against theories that focus on the way norms function in ordinary life was chiefly meant to stress how vital it is for a robust understanding of politics and law to determine what is beyond the transient, everyday effectiveness of a legal order. Against Hans Kelsen's claim that what comes before a valid constitution enters into force it is not for legal scientists to investigate, Schmitt argues that a theory concerned with law's ordinary activities is of little use. In Political Theology, he boldly claims that a theory of law must be primarily concerned with what happens when the daily order is suspended, when there is no order at all and everything is menaced by incipient chaos. In other words, a sound theory of law, Schmitt believes, should never take the existing order for granted and should tackle the crucial question of where this order comes from. On his reading, the theory of law reveals itself as a theory of sovereignty, one that is able to identify the fountain of the order, which is to say, the sovereign.

It is worth highlighting that Schmitt's insistence on the exception as the central focus of every genuine theory of sovereignty is instrumental in a sounder comprehension of the nature of norms: "It would be a distortion of the schematic disjunction between sociology and jurisprudence if one were to say that the exception has no juristic significance [...]. The exception appears in its absolute form when a situation in which legal prescriptions can be valid must be first brought about" (Schmitt 2005,

sovereign's decision proves effective when it successfully identifies the existential enemy (that is, the one whose existence poses a threat to the existence of the political community) and thus provide the background against which friends can recognize each other.

6 "The exception in jurisprudence is analogous to the miracle in theology" (Schmitt 2005, p. 36).

7 "Nomination is, when we stop to think of it, a very mysterious act which follows a logic quite similar to that of magic as described by Marcel Mauss. Just as the sorcerer mobilizes the capital of belief accumulated by the functioning of the magical universe" (Bourdieu 1998, p. 51). 
p. 13). Accordingly, when he writes that "the rule proves nothing; the exception proves everything" (Schmitt 2005, p. 15), he does not want to belittle the role of norms in the life of the law. Rather his aim is to stress something relevant about them: norms are placed in an ontogenetic relationship to the exception, such that the former emerge out of the latter. In this light, Schmitt's analysis in Political Theology proves a subtle theoretical argument: if we intend to make sense of the legal order, we need to investigate its origin. In the 1920s his conviction is that the origin of the law is a decision whereby the sovereign cuts out - that renders the German ent-scheidet, deriving from the Latin de-caedit and then de-cidit - the societal element which threatens the general homogeneity of the community. In this framework, however, sovereign is anyone who turns out to be able to make the proper decision, or rather, the one which successfully indicates the enemy and, based on that, creates an order.

In sum, in order to properly understand the "institutional turn" that I will shortly introduce, it is important to keep in mind that Schmitt's first concern in Political Theology is theoretical, as he himself emphasises by quoting Søren Kierkegaard: "If one wants to understand the general correctly, one only needs to look around for a true exception" (Schmitt 2005, p. 15). He aims to explain normality by investigating what brings it into life and to account for the way norms work by identifying their fountainhead.

Between the 1920s and the 1930s and above all early in the 1930s, Schmitt realises his decisionistic understanding of the legal order was flawed, as it fell short of its end: it failed to explain how norms work in everyday life and what brings normality into existence. He reaches the conclusion that, much as the exception helps explain the way a legal order is brought into force, it does not explicate how it reproduces and thrive. The celebrated theorist of the exception converts to a view that does not necessarily deny the relevance of such a key political notion, but certainly confines it to a liminal status. How come he reaches this conclusion? To cut a long story short ${ }^{8}$, Schmitt is prompted to revise his extreme and somewhat paradoxical view of an order created out of nothingness by his encounter with the theories of two prominent jurists, Maurice Hauriou and Santi Romano. These are two towering figures of what is today known as "classic institutionalism". I cannot explore their influential theories in this context. Suffice it to say that both these authors compellingly demonstrate that no legal order can be created ex nihilo, because it always constitutes the systematisation, or better, the institutionalisation of something which is produced by social actors within their social cradle in the practice of everyday life.

Evidently, Schmitt's new understanding of the legal phenomenon is barely reconcilable with an overemphasis on exception and decision, so much so that he comes to reject exceptionalism. In 1933, in the preface to the second edition of Political Theology, he points out that there was something missing in his previous theoretical framework: "I now distinguish not two but three types of legal thinking; in addition to the normativist and the decisionist types there is the institutional one" (Schmitt 2005 , p. 2). Decisionism, he explains, merely focuses on one "moment" and thus "runs the risk of missing the stable content inherent in every great political movement" (Schmitt 2005, p. 2). Whereas the Schmitt we are more familiar with was so affectionate to the exceptional and yet rare circumstances in which no order is at work and a sovereign decision has to be made, the Schmitt of the 1930s is looking for something stable and durable. Although the decision taken in exceptional moments is what brings a legal order into existence, there is something else that prompts a community

\footnotetext{
${ }^{8}$ This story is fully recounted in ANONYM.
} 
to durably comply with the norms of this system. This missing element is what once Schmitt himself used to consider far less interesting, that is, normality.

In Schmitt's institutionalism normality is by no means just a further element of the broad picture. Normality reshapes the ontogenetic relationship he had originally posited between norms and exception, to the extent that the latter loses much of its relevance. Schmitt de facto rejects his claim that the normal proves nothing and the exception everything. In his writing of the 1930s, and in particular in On the Three Types of Juristic Thought, he brings this theoretical amendment into light and provides a sound (albeit incomplete) justification. Although infected by his infelicitous and deplorable allegiance to the Nazi regime, in these writings Schmitt elucidates why normality is key not only to the subsistence, but also to the emergence of a legal order. The contents of the law cannot be originated by a sovereign decision. The sovereign is no longer an absolute decider over a dramatic disorder. By capitalising on his institutionalist predecessors, Schmitt recognises that without a set of social practices being stably developed in the social realm, no ordering decision can take place.

To offer a few more details, Schmitt's novel "institutionalist decisionism", which he calls "concrete-order thinking" (Schmitt 2004, p. 47), deems the law to be the shell of a substance which is the upshot of a long-standing and laborious activity of a social body. His new perspective can be summarised as follows. Law is structurally based on a dialectical relationship between normality and abnormality, where normality is comprised of the patterns of rules and conducts developed within the most widespread and age-old institutions that make a community that community ${ }^{10}$. Conversely, abnormality is what deviates from the courses of action, rules, and interactional models that characterise these institutions, and thus threatens the normality they nurture. In stark contrast to his decisionist phase, however, Schmitt now claims that the dialectic between normality and abnormality is at work well before a sovereign claims to instate the political order. The order of normality comes before any exception and needs no creative intervention on the part of a miraculous decider. If this is so, then law is not the upshot of a creation ex nihilo, but an instrument that is meant to select patterns of rules and conducts developed within institutions and grant them the status of compulsory standards, binding on the entire community. The law is a sieve that separates the institutional models that are believed to be crucial to the existence of the community and that folds them in its (coercive) arms.

What is, then, the space Schmitt reserves to politics? Certainly, it loses the foundational role it played in the theory of exception. Nevertheless, there is an essentially political element involved in the creation and maintenance of an institutional setting, in that the law - under the judicious guidance of a Leader - has to perform a process of selection whereby a restricted set of institutional practices are assigned the legal status of compulsory standards. This selection, in Schmitt's view, is key to the subsistence of a community, because it provides the criteria of normality whereby a range of individuals are turned into a homogenous community. In other words, normality is the possibility condition for sameness, as the members of a body politics mutually recognise each other in the light of a joint commitment to a shared ethical substance.

Although the reiterated reference to a Leader are to be attributed Schmitt's opportunistic choice, his institutional theory nicely explains how politics is all about the taking care of the normality which social subjects produce in their everyday life and that is continually exposed to the capricious

\footnotetext{
${ }^{9}$ See ANONYM.

${ }^{10}$ Schmitt's notion of institutions is far from refined and, in the examples he provides here and there, he puts together different types of institutions, such as the family, the army, or the church. In other words he fails to distinguish institution if term of the verbalisation of rules, formalisation of knowledge and degree of specialisation.
} 
flexibility of social change. Moreover, he illustrates how normality and sameness are cognate phenomena, as the same emerges out of the normal, while the normal is what it is only insofar as it succeeds in indicating what is the same. Doubtless, whereas the reference to a homogenous, thick, almost visible ethical substance at the heart of the community is far away from Wittgenstein's flexible and varying forms of life, Schmitt's new understanding of an intrinsic relation between sameness and normality bear many resemblances to the latter's. Not only does sameness come before and provide the conditions for difference to exist. Much more importantly, the site where sameness is produced is the practice itself, where agents are directly involved in the categorisation of reality, the production of meanings, the creation of rules.

\section{Performative citation and the creation of sameness}

Let me try to recapitulate my argument thus far. My goal in the preceding pages was to draw attention to the relationship among sameness, normality, and the constitution of social groups. I argued that, on account of the special nature of meanings, the very process of transmitting meanings is the primary vehicle of sameness. At this point, however, I incurred the dilemma of what is the source of sameness. I turned to Schmitt's troubled relation with normality because it casts light on the weaknesses of the idea that sameness is yielded by the act of a political demiurge. If in the 1920s it was already clear to his mind that " $[\mathrm{t}] \mathrm{o}$ recognize a class of things is to polarize and to exclude" and that such process always "involves drawing boundaries" (Douglas 1987: p. 60), after a decade Schmitt comes to the conclusion that sameness can never be the outcome of a miraculous decision: sameness pre-exists any human activities, from the making up of meanings to the introduction of legal norms. Sameness, now Schmitt reckons, is to be found in the normal life of widespread institutions, which behoves the law to protect and support. However, his texts do not offer a thorough theoretical justification for his penetrating insight.

Although Wittgenstein takes no notice of the political relevance of the production of sameness, he has clearer ideas on how the whole process is originally set in motion. It is my claim that his remarks provide a sound theoretical background for the scenario painted by Schmitt.

Wittgenstein believes that the dilemma of how sameness comes about can be solved by looking at the way in which standards materialise. Though he cannot be said to be sufficiently clear on this point, I believe David Bloor to offer a compelling interpretation of Wittgenstein's basic perspectives. Bloor (1997, p. 33) argues that standards emerge out of a self-referring activity. More in particular, a practice of citing is involved, whereby a given performance becoming a standard is occasioned by one's "commenting on the performances of others, and of one's self". In other words, the rule is brought into existence within and through the practice of citing and invoking it at the very moment of its first appearance. Therefore, in a truly Wittgensteinian spirit (Voltolini 2010), the dilemma dissolves. The activity of creation is entirely resolved into the practice itself when people draw their attention to a given performance and tease it out of the flexibility of social interaction by providing, most often unintentionally, a stable, objectified, and transmissible description of it.

Bloor (1997, p. 33) points out that, once the performance is rendered into a standard, it becomes a "medium of self-understanding". The standard turns out to be that in respect to which one performs subsequent actions and accepts to be assessed. The standard turns into a means for giving account of a certain set of actions, and, precisely because of that, produces sameness and distinction at one and the same time. It truly becomes the Bourdesian principle of vision and division that allows a group to 
exist qua group and to recognise those who do not belong to it. In short, the construction of sameness gets underway with a performative citation of something in respect to which something else is to be done and assessed. Once the performative force has exerted its effects on a given instance, this becomes paradigmatic and provides the monolingual mindset for social agents to share a common account of their surroundings and to assess and criticise each other. The aura of obscurity and magic that surrounds the production of standards dissipates when we realise that the agents themselves yields rules and institutions through their own performative acts.

This analysis exhibits two major strengths. On the one hand, it rehabilitates the role of social subjects in the production of institutional frameworks. For, it is the citational activity of individuals that singles out performances and turns them into standards. On the other hand, this activity is not relegated to individual's mind, as for example John Searle's (2010) influential analysis of the institutional world submits. Such a creational enterprise requires individuals to be involved in an actual and public interactional exchange. While actions must be concretely performed in the social theatre in order for agents to comment on them and to render them into paradigms, agents are required to concretely perform other actions under the guidance of such paradigms. This process is entirely performative, to the extent that what resides in people's mind turns out to be almost irrelevant ${ }^{11}$.

(This interpretation of) Wittgenstein compellingly demonstrates that no miraculous, sacred, and supra-personal power is involved in the creation of institutional standards ex nihilo. The integration of such insights into the nature of institutions with Schmitt's institutionalist view of how legal norms work in relation to a pre-existing normality is conducive to a convincing account of the way in which the legal order of liberal regimes oversees and protects social order.

In what follows I will try to expunge the conservative and reactionary elements of Schmitt's institutional view and to plunge it into the analytical framework based on Wittgenstein's remarks on standards. The upshot of such an unholy union will be an analytical framework able to account for how the liberal legal order operates to assure sameness and to defend normality. The hypothesis I will advance is that the legal norms of the liberal legal order allow, so to speak, a "bounded" renegotiation of the institutional models that they incorporate, one which confirms the models and reinforce the normality that underpins them. ${ }^{12}$

\section{Normalisation at work? the changing face of same-sex struggles}

By and large, the standard view on liberalism is that it gives birth to a political setting that seeks to accommodate a plurality of views about how individuals should live their lives (Kelly 2004). To this end, liberal policies do not endorse any theory of personal morality, but rather set limits on the scope of action of the various moral and political perspectives that inhabit democratic countries. Liberalism

\footnotetext{
${ }^{11}$ I provide a more detailed argument for the key role of publicness in the production of standards in ANONYM. with a view to justifying H.L.A. Hart's (genuinely Wittgensteinian) notion of practice.

${ }^{12}$ I would like to clarify that, in arguing so, my aim is not to prove that the law of liberal regimes is innately bad or unfair. If, as I have argued, every system of rules is inevitably exclusionary because it needs to create sameness, saying that liberal law is exclusionary because it tends to create sameness does not add up to saying that it is bad or unfair. The norms of a legal system, like the norms of every normative system, cannot be but exclusionary, precisely because every system of rules is innately based on a polarisation that involves exclusion and the drawing of boundaries (see also Cooper 2004: Chap. 3). Accordingly, my main goal is not to launch an attack on the political and legal structure of liberal states as such. Rather, I will seek to lay the foundation for a sounder understanding of what liberal regimes offer in the accommodation of difference, with a view to determining whether their offer may at times turn out to be a disguised strategy to prompt unnormalized subjects to trade in their troubling differences for an acquiescent assimilation.
} 
achieves that by opening up a bordered sphere of mutual interaction where everybody can contribute to the government of society. Within this public sphere, people can freely and jointly choose the terms of cooperation and co-existence, while the state, by enforcing rules that protect individual freedoms, makes sure that in the private sphere nobody can harm anybody else. In the private domain, people cannot be hindered from conducting their lives as they see fit, provided that their actions are not detrimental to the life of others. In short, a definite set of freedoms and the sacredness of the public/private divide comprise the basic idiolect of the law of liberal legal regimes: in the public sphere people make decisions on what concerns everyone as a member of the political community, whereas in the private sphere they are free to organise their existence in accordance with the models they prefer and the ideas of good life they hold.

Negotiations about what belongs to the private and what to the public have always been a source of polemics within liberal polities. Among the many issues that cut across this boundary, the family and its regulation turns out to be a very crucial one, for two main reasons. On the one hand, the family is regarded as an indispensable pillar of human association, the one that prove foundational to the existence of society (Calhoun 2000). On the other hand, the domain of the family is regarded as the domain of the intimate and the private, to the extent that some liken the distinction between public and private to the one between the impersonal and the intimate (Cooper 2004). Hence, governing the family entails control on a key site of the private domain whose effects on the domain of the public are uncountable ${ }^{13}$. It is no coincidence that nowadays most of the struggles of sub-state groups (whether religious or ethnic) in many Western countries concern family governance and the degree of autonomy that groups could or should be granted in the regulation of intimate relationships (Witte \& Nichols 2013).

At present the traditional understanding of family as a monogamous relationship between a man and a woman and their progeny is under siege, as in a growing number of Western countries samesex couples are officially allowed to enter marriage while in others they can register as civil partners. Although in some states the recognition of same-sex unions is still a hot topic, it can hardly be denied that the way to a deep rethinking of the notion of family and its essence has been paved. Nonetheless, according to some scholars (Barker 2013; Franke 2012; Richardson 2004), the current reworking of this vital practice, which has to do with the very existence of liberal states, is being conducted in such a way as to achieve two principal goals: to reinforce the role of family within the political community and to integrate 'good' lesbians and gays in order to minimise much more threatening unconventional sexualities.

Diane Richardson (2004) dwells on how the extension of rights connected to a fully-fledged citizenship ends up being instrumental in "the "normality' of being gay," that is, the full inclusion of homosexuals in the body politic as 'good citizens' who deserve complete integration into mainstream society. For Richardson, there are grounds to suspect that the current enormous attention to homosexual rights is conducive to the reinforcement of a traditional idea of sexuality which forms part of the upbringing of the good citizenship. More in particular, framing gay rights in terms of recognition of same-sex unions is fostering two key aspects of the traditional Western view of sexual

\footnotetext{
${ }^{13}$ Needless to say, this line of reasoning has always been the spearhead of the feminist campaign against patriarchy and compulsory heterosexuality. Feminist critics have denounced the "sacredness" of privacy and the right to be "left alone by the state, certainly in one's home and in one's bed, as a cover that hides rampant sexual abuse and domestic violence" (Cornell 1998, p. 40). In particular, some feminist scholars believe marriage to be the linchpin of the patriarchal structure of the heterosexual family and as an institutionalised form of heterosexuality that informs family and identity (Rich 1983; Richardson 1996).
} 
life: first, in spite of family being a vital element of civil society, the organisation of intimate relationships has to be couched as a private matter; secondly, its regulation has to be modelled on the conventional idea of union based on a long-term, committed, monogamous relationship.

Other empirical studies support the conclusion that the progressive convergence between straight and gay ways of living is sanctioning the triumph of the Western model of family, that is to say, the "young, white, married, heterosexual, able-bodied, family with bread-winning husband, dependent wife and children who share a residence and whose central relationship will be monogamous and last forever" (Weeks, Heaphy, and Donovan 1999, p. 706). Even though such conquests cannot be hastily demoted to forms of new subjugation (Stychin 2004), critics point out that the recognition of same-sex rights is both swelling the ranks of good, normal citizens and creating new types of excluded and marginalised sexualities (such as prostitutes, divorcees, promiscuous, unwed parents and so on).

In a recent cross-national study on the recognition of same-sex marriage, Nicola Barker (2012) draws on an extensive range of literatures - mainly feminist and queer - to argue that marriage is currently being presented as the only way to get access to a set of right, benefits, and privileges that are necessary to the governance of unions. This, she claims, is not only affecting the agenda of LGBT movements, but even more importantly prevents a careful assessment of what "it actually is that some same-sex couples are seeking access to and what it means to be married, legally, socially or ideologically" (Barker 2012, p. 12). Barker's point is that the pursuit of equal rights and responsibilities through marriage takes it for granted that legal 'rights and responsibilities' can really "provide 'the solution' to inequality" (Barker 2012, p. 169). In reality, as other studies seems to attest, what is being re-enforced is the seemingly natural connection between romantic love and marriage, which was typical of heterosexual coupledom, to the extent that respectability and acceptability can only be obtained through the lexicon of long-life, monogamous coupledom sanctified by marriage (Ammaturo 2014; ANONYM.; Franke 2004; Ruskola 2005).

In short, whether in civil partnerships or conventional marriage, unions between persons of the same sex are now legally regulated in most European member states, while the US and other European countries seem well on the way to removing legal impediments to them. Despite this, as the critiques I mentioned so far contend, the revision of social values and legal norms about homosexuality is both a drive for change and a reassertion of conventional ideals about proper kinship relations. In particular, same-sex marriage is believed to reinstate a conventional ideal of marriage, which only a few years ago was on the wane. Radical and left-wing critics maintain that current legal developments relative to marriage and unions are (at least partly) affected by biases that theorists define as "heteronormative" (Warner 1993) - whereby the form and structure of non-heterosexual relationships are modelled on existing heterosexual ones - and "homonormative" (Duggan 2003) - whereby homosexual individuals struggle to get access to those state institutions that erstwhile liberationist movements viewed as the root cause of their oppression. As a consequence, if contemporary legal regulation and social perception (despite regional variations) have come to terms with the idea, developed in the fields of social and cultural anthropology (Franklin and MacKinnon 2001; Schneider 1984), that kinship is not necessarily based on genetic ties, the pivot around which transformations in family law are being brought about is the conventional family. Current reformulations of the basic legal notions of family and family life leave untouched a seemingly unvarying trait of Western kinship, namely, the nuclear couple as the building block of legitimate kinship. Acceptability and respectability are conferred on same-sex unions only as long as they are amenable to the couple- 
form, and are willing to enjoy the legal status which is bestowed on their unions as nuclear units (Cobb 2012).

\section{How the liberal legal order thinks: secondary legal norms as preferential pathways}

How could the push towards sexual equality eventuate in the reassertion of conventional coupledom? To answer this question I need to look at the nature of the basic instruments of legal regulation through the lens of the analysis developed in the first three sections.

In his pioneering critique of same-sex marriage as a respectability-conferring tool, Michael Warner laments the reduction of homosexual rights to a matter of individual preference that the state is called upon to accommodate insofar as it is obliged to grant its citizens equal treatment. In doing so, he sheds light on the public character of this transition. At face value, the transformation of the homosexual imagery brought about by normalisation has to do with the private choice of homosexual individuals who want to marry in order to regulate their relationship in keeping with official legal provisions and to send out a message of mutual and enduring love. In reality, according to Warner (1999, p. 96), marriage is hardly "something you do privately, as a personal choice or as an expression of taste". This seemingly private act turns out to be a public operation that impinges on homosexual sexuality in such a way that some homosexuals - those who are ready to come to terms with an


the ranks of the good citizens and to be accepted (as alike) by the bulk of the society. At the same time, however, others, less respectable and less acceptable sexual minorities, whether homosexual or not, continue to be pathologised and marginalised as unable to fit the good society ${ }^{15}$.

In this regard, Warner's can be viewed as a critical attempt to chart how the liberal legal order operates on the social domain as far as the protection of normal sexuality is concerned. When Warner (1999, p. 82) claims that marriage "sanctifies some couples at the expenses of others", he is not simply pointing his finger at the benefits that some people can get while others are forced to lag behind. Warner's main concern seems to be of a conceptual type, especially when he addresses law's "selective legitimacy" (1999, p. 82). The crux of his argument is that marriage, as a legal institution, is not just a distribution mechanism for rights and privileges among citizens. Much more significantly, this mechanism wields a symbolic power that establishes a system of differences among citizens. For, one of the main consequences of law's selective legitimacy is the disciplining of those who do not fit the category produced by the legal system, those who cannot follow the path of the power-conferring rule of marriage and thus are structurally unable to bring new states of things into existence: "As long as people marry - Warner (1999, p. 96) points out -, the state will continue to regulate the sexual lives of those who do not marry" "16. These people fall outside the practice of good sexuality, supported and reflected by state policies, because this practise possesses a specific nature that is incompatible with the rules, models, and dynamics developed in the practices of "deviant" sexual minorities.

\footnotetext{
${ }^{14}$ On this complex transition, see Harris 2006. More in general on gay liberationism and its theoretical and ideological background, see Brookes 2009.

${ }^{15}$ The way non-monogamies are treated as they are read against the "mononormativity" of monogamous coupledom is a glaring example. See e.g. Emens 2004; Klesse 2007; Klesse 2014; Sheff 2011.

${ }^{16}$ To be fair to the huge number of theorists and practitioners who do not believe marriage to be so detrimental to homosexual sexualities and even think that it is the best strategy to gain the rights they deserve as equal citizens, see Bernstein and Taylor 2013. The book presents a variety of perspectives (most of them favourable to same-sex marriage) in order to debate the advantages and the disadvantages of homosexuals being recognised the right to marry. See also Cox 2014.
} 
In the remaining pages of this article, capitalising on the arguments developed in the preceding sections, I would like to contribute to the critical literature on homosexual normalisation by developing an alternative hypothesis on why such a process is at work and how it is connected to the legal regulation of sexuality. In effect, much as Warner's and other queer theorists' analyses prove highly instructive, they fail to fully identify the role played by the law and its relation to social signification ${ }^{17}$. To achieve this aim, I would like to look at that type of rules that in jurisprudential thinking are generally defined "secondary" or "power-conferring" (Hart 1994). These are rules that do not prescribe or prohibit specific conducts but confer authority in two different ways. On the one hand, they enable private individuals to bring new states of things into existence as long as their actions are performed in accordance with specific legal provisions - to be private legislators, as Hans Kelsen (1945, pp. 136-137) put it. On the other hand, these rules empower officials to recognise, amend, and apply other rules ${ }^{18}$. Power-conferring rules represent a pivotal element of a juridicopolitical setting inasmuch as they encapsulate shared and stable models of organisation and mandate specific conducts to comply with these models. In particular, when they are addressed to private individuals, secondary rules indicate what is to be done both in order to change one's status (for example, from single to wedded) and in order to make one's actions have specific effects on reality (for example, to bequeath an estate). In other words, the law prescribes certain pathways to make it sure that one's doing something may have the effects one intends to bring about.

The common description of this type of rules can be misleading, for it tends to convey the idea that people are genuine creators of something. For instance, in his ground-breaking analysis of the concept of law, H.L.A. Hart (1994, pp. 34-35) claims that, unlike rules that confer powers, rules that prescribe conducts (primary rules) are structured in such a way that "we can distinguish clearly the rule prohibiting certain behaviour from the provision for penalties to be exacted if the rule is broken, and suppose the first to exist without the latter." Hart means that behind a rule of conduct there is a model that predates the rule, while no such model can be found behind a power-conferring rule. The latter type of rule confers legitimate authority (whether private or public) to constitute entirely new entities. This reading, however, omits to say that in order for a secondary rule to confer power, a specific model has to be officially established as the paradigm. Here Wittgenstein's investigation on the emergence of standards and Schmitt's analysis of normality prove revealing. On the one hand, Wittgenstein illustrates how, once this model has been officially instituted as the standard model, the actions that fall within its scope are thought, performed, and assessed as correct or incorrect in its light. On the other hand, Schmitt explains that, despite any claim to individual freedom and equality, legal standards are intended to protect pre-existing social standards and to prevent the appearance of potentially harmful alternatives. Hence, pace Hart, there is no power-conferring rule that is not meant to enshrine a pre-existing model and to repress (at least as an inadvertent outcome) unwanted types of conducts that could threaten the model.

This is evidence that secondary, power-conferring rules contribute to giving a specific shape to human co-existence. As Schmitt realised in the 1930s, rules defining specific models of conduct within given institutions are key to (what he views as) a solid and vigorous political community. The

\footnotetext{
${ }^{17}$ Relevant exceptions are works by queer theorists with legal background, such as e.g. Katherine Franke, Janet Halley, and Teemu Ruskola. Yet, my analysis differ from theirs insofar I claim that tracing the effects of legal regulation entails a sound analysis of social practices and their relation to the legal order.

${ }^{18}$ The literature on secondary rules and the confusions that surround their nature is abundant. For a detailed discussion, with specific reference to Hart's legal theory, see ANONYM., where readers can find a detailed reference list.
} 
state, he believes, has the duty to protect such legally recognised models and must make sure that legal officials are vigilant on their strict application. This explains why one of founding fathers of contemporary libertarianism, Friedrich von Hayek, bemoaned the growing relevance of this type of rules in Western democracies. In The Principles of a Liberal Social Order Hayek writes:

\begin{abstract}
The character of those universal rules of just individual conduct, which liberalism presupposes and wishes to improve as much as possible, has been obscured by confusion with that other part of law which determines the organization of government and guides it in the administration of the resources placed at its disposal. It is a characteristic of liberal societies that the private individual can be coerced to obey only the rules of private and criminal law; and the progressive permeation private law by public law in the course of the last eighty or hundred years, which means a progressive replacement of rules of conduct by rules of organization, is one of the main ways in which the destruction of the liberal order has been effected. (Hayek 1967: pp. 168-169) $)^{19}$.
\end{abstract}

In other words, Hayek considers those rules whereby the state determines how society should be organised as the most incisive instrument in the hands of the government to rule human practices and to restrict spontaneous and voluntary modes of self-organisation. It is no coincidence that, as a glaring example of a state which illiberally employs legal norms to mould society, Hayek (1967: p. 169) refers to Schmitt's institutional portrayal of the German post-positivist legal order: Schmitt applauds the outright replacement of cold and bloodless norms of conduct with the norms that emerge out of concrete institutions and instruct Germans on how to conduct their lives in keeping with their age-old tradition. Hayek intuits the pervasive effectiveness of this legal instrument: secondary rules present themselves as inoffensive legal norms that empower people to do things with the law, whereas its strategic use on the part of the state may trigger a process of subjection and normalisation. Hayek's contention is that the state holds sway on the life of its citizens not by the use of fearful emergency powers (which can be sometimes the case, but less often than not). The state achieves this end by inducing citizens to go down certain paths, that is, to follow secondary rules that enable people both to have recourse to law's stock of legitimate force when disputes arise and to send out a message about their status and desires. Marriage is a case in point: far from being a mere opportunity for citizens to act as "private legislators", it is a straightjacket procedure to get the benefits that the state associates to a specific, well-defined institution.

\title{
The challenge to normality and the immunity response
}

Getting back to my initial analysis, I would like to argue that, more effectively than rules that prohibit or forbid conducts, rules that confer powers assure sameness by establishing roles and therefore by demarcating institutional figures that provide cognitive guidance on how to do things as role-players. Roles however are neither only nor primarily determined by the set of mandatory actions to be performed in specific circumstances. For they are characterised first and foremost by the stock of knowledge that the role-player is expected to possess (whether explicitly or not) in order to perform these actions when appropriate circumstances arise. Within an institutional framework marked out by

\footnotetext{
${ }^{19}$ It is worth remarking in passing that, while Hart deems the introduction of secondary rules to be the element that distinguishes developed societies from primitive ones - a "step forward as important to society as the invention of the wheel" (Hart 1994, p. 42) -, Hayek interprets the reliance on secondary rules as the hallmark of illiberal societies.
} 
power-conferring legal rules, these rules are not addressed to individuals as law-abiders, but to the members of a practice that is regulated by the law. Moreover, as Schmitt's institutional analysis reveals, the law does not forge institutional frameworks, but sanctions their existence and enforces the rules that are already at work within them (although legal recognition inevitably brings about changes and adjustments on the rules and structures that the law enforces). The pre-legal structure of institutional frameworks is so crucial to their existence and reproduction that, Schmitt avers, every legislator, and anyone who applies the law, is bound to face the dilemma of "either to accept and apply the given concrete legal concepts of the institution or to destroy the institution" (Schmitt 2004, p. 54 - emphasis added).

Schmitt's words offer a valuable key to the understanding of the normalisation process. The institutional framework that the law recognises and regulates is hardly a neutral field of interaction sensitive to the innovations introduced by members. It is a normative context whose existence is deeply rooted in a specific institutional history that binds changes to scarcely flexible paths. In the case of marriage and family, roles like mother and father, daughter and son, sister and brother, are not fungible labels that easily adapt to morphing circumstances. They are the accretion of rules that are supported by specific instructions and offer role-players a cognitive prism through which they approaches reality when they play that role. As I showed above with reference to the incest taboo, being a sister is not as much a matter of complying with rules as it is of knowing (at least implicitly) what conducts and expectations the set of rules that define the role of sister entails.

Doubtless, those who defend the progressive character of allowing same-sex couples to marry make the argument that, as the language of everyday life and its meanings change over time, so do institutional frameworks and their stock of knowledge. The revision of consolidated practices (whether promoted by legal reforms or by spontaneous societal developments) produce significant changes in the way people perform these practices and understand themselves when they play roles. For example, the role of parents in the era of assisted reproductive technology gets significantly altered as the possibilities of procreation multiply and the relevance of the dyad mother/father decreases (Hayden 1995; Dempsey 2010). On this account, like the revision of parenthood prompted by new technologies, the revision of the meaning of conventional marriage prompted by legal recognition of same-sex marriage seems destined to cause havoc in the traditional understanding of kinship and to pave the way for alternative models to sprout. These metamorphoses would play as concurring elements in a process able to confer visibility on the invisible and to make unliveable lives more liveable, like Judith Butler's Antigone's push toward "a new field of the human, achieved through political catachresis, the one that happens when the less than human speaks as human, when gender is displaced, and kinship founders on its own founding laws" (Butler 2000, p. 82).

Nevertheless, the structural limits imposed on such a political catachresis are several. Social change is not a free-floating process taking place in a vacuum. The cognitive resources employed to apply meanings in a subversive and potentially transformative way have to be found in the very semantic repertoire that is being put into question. The challenge to the bounds demarcated by the lexicon of the practice, which can be transformed only by reference to its meanings, and is supported by scarcely malleable legal provisions, ignites a reaction whereby deviant conducts and their meanings are integrated. Though this integration effects changes within the practice, the latter is capable of accepting what can be accepted and rejecting what could be lethal to the practice as a whole. In this scenario, Roberto Esposito's (2010) thesis of the category of immunisation being key to the modern paradigm of community can be of help. He explains that, whereas the words community 
and immunity share the reference to the term "munus" (whose intricate meaning runs from office and post to gift and obligation), the "immune" is the opposite of the "common". Modern political communities, Esposito points out, are founded on an immunity impulse that is "the clearest kind of negation" (Esposito 2010, p. 16), especially when it becomes foundational to the community. In fact, the community founds and recognises itself through an excision, whereby that which threatens the stability of widespread practices has to be eradicated. In my reading, however, this process of removal rarely takes the shape of overt and violent exclusion. Law exerts its exclusionary effects by means of a semantic renegotiation of meanings whereby the boundaries of normality have to be revised to fend off greater challenges. In liberal regimes, state law's immunity reaction expresses itself through violence only in extreme cases. More often than not, sameness is secured by prompting people to follow specific paths as they intend to exert legally (and publicly) recognised effects on reality.

Legal regulation reveals itself as a form of control on the production and revision of meanings: as soon as alternative practices emerge, these are selected according to their aptness to be integrated into the existing institutional frameworks. Law's chief immunity weapon is assimilation. Access to the set of benefits and rights associated to official institutions can be obtained only insofar as the conducts pursuing recognition can be narrated with recourse to a practical vocabulary which proves able to speak the language of the law (ANONYM.). In this reading, normality figures as the main rule of the game, whereas sameness turns out to be the only way to play by this rule. Accordingly, as Bourdieu, Douglas, Schmitt, Schneider, and Wittgenstein (as far as I understand them) suggest, normality and sameness do not form part of an imperceptible surveillance apparatus that holds sway on acquiescent subjects, consciously deployed by conservative and neoliberal juridico-political devices. Much more deeply tied to the very nature of human categorisation, the selective mechanism of liberal states builds on, and exalts, human beings' necessity to polarise and exclude, and thus to produce common meanings to provide mutually intelligible accounts of their practical environment.

In sum, the centripetal force of standard models, especially when they are backed by the legitimacy of legal recognition, unleashes its normalising effects precisely by allowing partial renegotiations over the traits that determine sameness, that is, over the characterising features of the roles that people are required to perform within institutional framework. In the case of marriage and its extension to homosexuals, legally married couples will no longer be those comprised of a man and a woman, but those comprised of two persons who choose to constitute a family and aim to make their reciprocal love public. If the difference of sex ceases to be a necessary feature, the link between marriage and a set of values, such as coupledom, romantic love, mutual fidelity, and the desire to rear children will even be reinforced, essentially because these are the elements that allow former excluded minorities to reach out to the heart of their fellow citizens (who nurture the same desires) and to get access to marriage. In much the same way, sameness will no longer imply reference to gender and blood, but to choice and mutual commitment: those who intend to make public their reciprocal choice are all alike and deserve the right to regulate their relationship in compliance with legal measures that once were reserved to couples of different sex. In the face of it, the arguments developed by opponents and supporters of same-sex marriage turn out to be impressively similar, based on a historical understanding marriage that is bound up with a set of social norms that safeguard the borders of the conventional monogamous family (Zivi 2014).

To conclude, let me answer a potential objection. My analysis might seem to suggest that there is no way out of normality, so much so that the reproduction of sameness, and, a foriori, marriage and other existing institutions are the only, though costly, options for sexual minorities to get the 
social visibility they strove for and the rights they deserve as citizens of a liberal state. However, this is not what my analysis implies. It is true that, as I argued so far, sameness and normality are constitutive of there being social groups and political communities. Yet, the most effective way to counter their harshest outcomes (such as abjection, marginalisation, and invisibility) is a widespread awareness of the role of sameness and normality. The seemingly neutral language of the law helps legal and political institutions to disguise their tendency to secure order through their selective mechanisms ${ }^{20}$. The institutional language of the state inevitably tends to treat as unspeakable and thus as non-existent those who suffer from the negative externalities of its policies. In the face of it, the frank admission that the law has to make exclusionary decisions to assure the stability of everyday life would grant those excluded more visibility, and would not confine them in the invisible space of marginal pathologies. They would not be regarded as deviances, eccentricities, and abnormalities, but as alternative options that pose a challenge to the existing normative framework and the values it supports. This is why I believe that a more open, perhaps harsher, confrontation among alternative models would convey the idea that the existing standard is just an instance of a reiterated action that has been transformed into a standard, and has no inborn traits that make it a standard by nature.

\section{References}

Agamben, G. (1998). Homo Sacer: Sovereign Power and Bare Life. Stanford, CA: Stanford University Press.

Ammaturo, F.R. (2014). 'The Right to a Privilege? Homonormativity and the Recognition of SameSex Couples in Europe'. Social \& Legal Studies 23(2), 175-194.

Baker, G.P., \& Hacker, P.M.S. (2009). Wittgenstein. Rules, grammar and necessity. Essays and exegesis of $\$ \S 185-242,2^{\text {nd }}$ ed. Malden, MA: Blackwell Publishing.

Barker, N. (2012). Not The Marrying Kind. A Feminist Critique of Same-Sex Marriage. Houndmills: Palgrave Macmillan.

Berger, P., \& Luckmann, T. (1966). The Social Construction of Reality. A Treatise in the Sociology of Knowledge. London: Penguin.

Bernstein, M., \& Taylor, V. (Eds.) (2013). The Marrying Kind? Debating Same-Sex Marriage within the Lesbian and Gay Movement. Minneapolis, MN: University of Minnesota Press.

Bloor, D. (1997). Wittgenstein, Rules and Institutions. London: Routledge.

Bourdieu, P. (1990). The Logic of Practice. Stanford: Stanford University Press.

Bourdieu, P. (1998). Practical Reason. On the Theory of Action. Stanford: Stanford University Press.

\footnotetext{
${ }^{20}$ A quick example might be of help. The case of Burden v. UK (2008) adjudicated by the European Court of Human Rights is characterised by a conflict between the first judgment of a Chamber within the Fourth Section and the final one of the Grand Chamber. The Court was called upon to determine is two elderly sisters, who had lived together, in a stable, committed and mutually supportive relationship, could be exempted from paying the inheritance tax when one of the two would die. To achieve that, they wanted to be recognised as a couple under the Civil Partnership Act. While both the Chambers agreed that the two sisters could not be recognised the status of partners, the motivation they provided were so different that a few sitting judges of the Grand Chamber wanted to provide either concurring or dissenting opinions to voice their strong preference for the earlier decision. In short, the Chamber's motivation revolved around the state's right to privilege some models of family and kinship through policy measure and to discourage others, while the Grand Chamber's one was based on an alleged essence of the connection between siblings, based on consanguinity, that inexorably prevents them to enter into marriage or partnership, which possess a different, incompatible essence. Against the majority opinion of the Grand Chamber, some Justices claim that the state should make explicit its legitimate right to exclude someone at the expenses of others.
} 
Brookes, L. (2009). Gay Male Fiction Since Stonewall: Ideology, Conflict, and Aesthetics. London: Routledge.

Butler, J. (2000). Antigone's Claim. Kinship Between Life \& Death. New York: Columbia University Press.

Calhoun, C. (2000). Feminism, the Family, and the Politics of the Closet: Lesbian and Gay Displacement. Oxford: Oxford University Press.

Cobb, M. (2012). Single: Arguments for the Uncoupled. New York: New York University Press.

Conrad, R. (Ed.) (2010). Against Equality: Queer Critiques of Gay Marriage. Lewiston, ME: Against Equality Publishing Collective.

Cooper, D. (2004). Challenging Difference. Rethinking Equality and the Value of Difference. Cambridge: Cambridge University Press.

Cornell, D. (1998). At the Heart of Freedom: Feminism, Sex, and Equality. Princeton: Princeton University Press.

Costa, P., \& Zolo, D. (2007). The Rule of Law: History, Theory and Criticism. Dordrecht: Springer.

Cox, B. (2014). Marriage equality is both feminist and progressive. Richmond Journal of Law and the Public Interest 17(4), 707-738.

Dempsey, D. (2010), Conceiving and Negotiating Reproductive Relationships: Lesbians and Gay Men Forming Families with Children. Sociology 44(6), 1145-1162.

Douglas, M. (1987). How Institutions Think. London: Routledge \& Kegan Paul.

Duggan, L. (2003). The Twilight of Equality? Neoliberalism, Cultural Politics, and the Attack on Democracy. Boston, Mass: Beacon Press.

Emens, E.F. (2004). Monogamy's Law: Compulsory Monogamy and Polyamorous Existence. NYU Review of Law \& Social Change 29, 277-376

Esposito, R. (2010). Communitas. The Origin and Destiny of Community. Stanford: Stanford University Press.

Foucault, M. (2008). The Birth of Biopolitics: Lectures at the College de France, 1978-79. Basingstoke: Palgrave Macmillan.

Franke, K.M. (2004). The domesticated liberty of Lawrence v. Texas. Columbia Law Review 104, 1399-1426.

Franke, K.M. (2012). The Curious Relationship of Marriage and Freedom. In Scott E., \& M. Garrison (Eds.). Marriage at a Crossroad, Cambridge: Cambridge University Press.

Franklin, S., \& McKinnon, S. (2001) (Eds.). Relative Values: Reconfiguring Kinship Studies. Durham, NC: Duke University Press.

Freeman, E. (2002). The Wedding Complex: Forms of Belonging in Modern American Culture. Durham, NC: Duke University Press.

Harris, A.P. (2006). From Stonewall to the Suburbs? Toward a Political Economy of Sexuality. William \& Mary Bill of Rights Journal 14(4), 1539-1582.

Hart, H.L.A. (1994). The Concept of Law. $2^{\text {nd }}$ ed., Oxford: Oxford University Press.

Hayden, C.P. (1995). Gender, genetics, and generation: reformulating biology in lesbian kinship. Cultural Anthropology 10, 41-63.

Hayek, F.A. (1967), "The Principles of a Liberal Social Order". In New Studies in Philosophy, Politics, Economics and the History of Ideas. London: Routledge and Kegan Paul, 160-177.

Hunnings, G. (1988). The World and Language in Wittgenstein's Philosophy: Fruit Vendors and Civil Servants. New York: SUNY Press. 
Kelly, P. (2004). Liberalism. Cambridge: Polity.

Kelsen, H. (1945). General Theory of Law and State. Cambridge: Harvard University Press.

Klesse, C. (2007). The Spectre of Promiscuity: Gay Male and Bisexual Non-monogamies and Polyamories. Aldershot: Ashgate.

Klesse, C. (2014). Poly Economics - Capitalism, Class, and Polyamory. International Journal of Politics, Culture, and Society 27(2), 203-220.

Mouffe, C. (2000). The Democratic Paradox. London: Verso 2000.

Polikoff, N.D. (2008). Beyond (Straight and Gay) Marriage. Valuing All Families under the Law. Boston: Beacon Press.

Redding, J.A. (2010). Dignity, Legal Pluralism, and Same-Sex Marriage. Brooklyn Law Review 75, 791-863.

Rich, A. (1983). Compulsory Heterosexuality and Lesbian Existence. In A. Snitow, C. Stansell, \& S. Thompson (Eds.), Desire: The Politics of Sexuality (pp. 212-241). London: Virago.

Richardson, D. (2004). Locating Sexualities: From Here to Normality. Sexualities 7(4): 391-411.

Richardson, D. (Ed.) (1996). Theorising Heterosexuality: Telling it Straight. Buckingham and Philadelphia: Open University Press.

Ruskola, T. (2005). Gay rights versus Queer Theory. Social Text 23 (3-4), 235-49.

Schneider, D.M. (1980). American Kinship. A Cultural Account. Chicago: The University of Chicago Press, $2^{\text {nd }}$ ed.

Schneider, D.M. (1984). A Critique of the Study of Kinship. Ann Arbor, MI: University of Michigan Press.

Schmitt, C. (1996). The Concept of the Political. Chicago: The University of Chicago Press.

Schmitt, C. (2004). On the Three Types of Juristic Thought. Westport, CT: Praeger.

Schmitt, C. (2005). Political Theology: Four Chapters on the Concept of Sovereignty. Chicago: The University of Chicago Press.

Searle, J.R. (2010), Making the Social World: The Structure of Human Civilization. Oxford: Oxford University Press.

Sheff, E. (2011). Polyamorous Families, Same-Sex Marriage, and the Slippery Slope. Journal of Contemporary Ethnography 40(5), 487-520.

Sluga, H. (2011), Wittgenstein. Oxford: Blackwell.

Stychin, C. (2004). Same-sex Sexualities and the Globalization of Human Rights Discourse. McGill Law Journal, 49: 951-968.

Taylor, C. (1993). To Follow a Rule... In C. Calhoun, E. LiPuma \& M Postone (Eds.) Bourdieu: Critical Perspectives. Cambridge: Polity Press.

Voltolini, A. (2010). Is Wittgenstein a Contextualist? Essays in Philosophy, 11(2), 150-167.

Warner, M. (1993) (Ed.). Fear of a Queer Planet: Queer Politics and Social Theory. Minneapolis: University of Minnesota Press.

Warner, M. (1999). The Trouble with Normal. Sex, Politics, and the Ethics of Queer Life. Cambridge, Mass.: Harvard University Press.

Weeks, J. (1998). The sexual citizen. Theory, Culture and Society, 15(3-4): 35-52.

Weeks, J., Heaphy, D. and Donovan, C. (1999). Citizenship and Same Sex Relationships. Journal of Social Policy, 28(4): 689-709.

Williams, M. (1999), Wittgenstein, Mind and Meaning. Toward a Social Conception of Mind. London: Routledge. 
Witte, J., \& Nichols, J. (2013). Who Governs the Family?: Marriage as a New Test Case of Overlapping Jurisdictions, Faulkner Law Review 4, 321-349.

Wittgenstein, L. (2009). Philosophical Investigations. Oxford: Blackwell.

Zivi, K. (2014). Performing the Nation: Contesting Same-Sex. Marriage Rights in the United States. Journal of Human Rights 13, 290-306. 